\title{
Intergovernmental Nuclear Fuel Banks: Re-examined
}

\author{
Gabriella Gricius
}

\begin{abstract}
The effectiveness of the nuclear non-proliferation regime is no longer as sturdy as it once was and new infusions of creativity are greatly needed. Concentrating on positive incentives may better promote non-proliferation. Incentives targeting industry have a higher chance of success due to their vast influence in multiple governments. The IAEA's ElBaradei Report is one conceptualizatoin of an intergovernmental nuclear fuel supply bank. As a multilateral approach, nuclear fuel banks promote more opportunities for diplomacy amongst states. While it is only one approach to overcoming the current crisis of the non-proliferation regime, it has the potential to make a huge difference in how the world handles nuclear power on a supranational basis.
\end{abstract}

Keywords non-proliferation, IAEA, economic interdependence, multilateralism, nuclear power

\section{Introduction}

Countries aiming to act unilaterally in an increasingly interconnected world often provoke unforeseen consequences. Accordingly, when the question of nuclear security arises, acting unilaterally is not a viable and sustainable option. Cooperation is not preferred-it is necessary. International institutions have not yet reached the point of failure, but their role in an increasingly unstable world means that innovation is needed. One way to show initiative is to look to industry in order to re-examine strategy. The establishment of intergovernmental fuel banks continues to be a viable proposal through which both government and industry could work together. In doing so, they can create positive incentives for countries to work towards more transparent and peaceful uses of nuclear energy. Fuel banks are currently expanding in countries such as Kazakhstan with the cooperation of the nearby regional power Russia. For now, however, these fuel banks exist only as a supplier of last resort in cases of disruption, rather than 
centers for innovation in nuclear energy usage. Furthermore, the proposal has not yet been lauded as the important step towards international collaboration that it represents. Why is that? These fuel banks exhibit the capacity to cooperate beyond mere signatures on a treaty; thus, revealing that in the face of weakening globalization, the non-proliferation regime still has the ability to remain meaningful.

Ultimately, the goal of those aiming to prevent the spread of nuclear weapons is simple and, at the same time, demonstrably difficult-global disarmament. For every country that remains capable of producing apocalyptic war through the use of such weaponry, there is a higher chance of "accident, miscalculation, and madness" (John F. Kennedy Presidential Library and Museum 2017). While before these results could have ended in border skirmishes or even conventional large-scale war, the existence of nuclear weapons now means that the consequences are planetary. However, practicality rears its ugly head when global disarmament is discussed. Countries claim that deterrence against other nations with nuclear weapons presupposes the removal of weapons from their own stocks. International treaties take this belief into account. Therefore, while global disarmament remains a theoretical goal, the nuclear non-proliferation regime focuses on two much more attainable objectives: preventing the spread of nuclear weapons and encouraging the peaceful use of nuclear energy. Negative reinforcement in this field does not play as large of a role. But we should look to different positive encouragements for a new approach and newer questions to pose. What incentives exist for countries to decrease their nuclear stockpile and forgo the development of such weapons? How do countries promote energy efficient research?

One possibility is outlined in the 2005 International Atomic Energy Agency (IAEA) publication Multilateral Approaches to the Nuclear Fuel Cycles Report, more commonly known as the "ElBaradei Report" (IAEA 2005). In this proposal, experts outline different concepts of intergovernmental nuclear fuel banks, "e.g. a contract under which a government would buy guaranteed capacity under specified circumstances" (ibid., 4). The approaches include everything from IAEA ownership to the possibility of fuel sharing. Similar to the development of the European Union as a precautionary measure against further war on the European continent, intergovernmental fuel banks are meant to be a mechanism that prevents misunderstanding in the nuclear field.

\section{Background}

Due to the unimaginable destructive power that a select number of countries possess, the weaponization of the atom was almost immediately followed by the creation of the nuclear non-proliferation regime. Both bilateral treaties signed 
between competing world powers-the Soviet Union and the United Statesand multilateral treaties signed by a wider range of countries dominated the policymaking of the late twentieth century. The most famous of these is the Treaty on the Non-Proliferation of Nuclear Weapons (NPT). Originally signed in 1968, this treaty is reviewed and signed every five years by its 190 signatories. The treaty essentially states that the nuclear weapon states (the United States, Russia, the United Kingdom, France, and China) will share the technological benefits of nuclear energy while advancing towards disarmament. This, in and of itself, is a positive reinforcement scheme. Non-nuclear weapon states will accede to not pursue nuclear weapons in exchange for this knowledge. However, neither India nor Pakistan have signed this treaty; rather, both countries have declared their possession of nuclear weapons. In addition, Israel has not signed the treaty and therefore remains ambiguous by neither confirming nor denying their obtainment of nuclear weapons. North Korea withdrew from the NPT in 2003 after testing nuclear weapons and declared itself a nuclear power in 2012. While the treaty has been in place for forty-nine years, it begs the question: how useful is a positive reinforcement scheme? Would North Korea have not pursued nuclear weapons with the similar positive reinforcement scheme of a fuel bank? One main criticism is that although countries have agreed to not develop this weaponry in principal, it has not stopped nuclear weapon states from improving upon these weapons nor enforced efforts towards disarmament.

Despite these criticisms, the NPT treaty remains, at the very least, intact. Other more specific disarmament-based bilateral treaties are beginning to fall by the wayside in favor of a more modern, flexible approach. In 2016, for instance, Russia suspended the Plutonium Management and Disposition Agreement (PMDA) - a bilateral treaty that had been in place for sixteen years between the United States and Russia. Although Russia claimed that the suspension was primarily due to the United States changing its disposal policy, both countries now do not have the contractual obligation to dispose of thirty-four metric tons of weapon-grade plutonium (Goenka 2016).

Other bilateral agreements between the United States and Russia remain, but new uncertainty within the global political system means that even previously signed treaties such as New Strategic Arms Reduction Treaty (START) are called into question. Signed in 2011, New START was negotiated by former President Barack Obama and current Russian Prime Minister Dmitry Medvedev. The main objectives are to halve the number of strategic nuclear missile launchers by 2021, when presumably the treaty could be extended if necessary. However, during an official call with President Vladimir Putin, President Trump called the agreement "a bad deal negotiated by the Obama administration." Although it does not immediately suggest that New START will not be extended, it calls into question the stability of the non-proliferation regime if two of the key players no longer are invested in decreasing nuclear stockpiles (Landay and Rohde 2017). 
Figure 1. Global Trends in Armed Conflict, 1946-2017

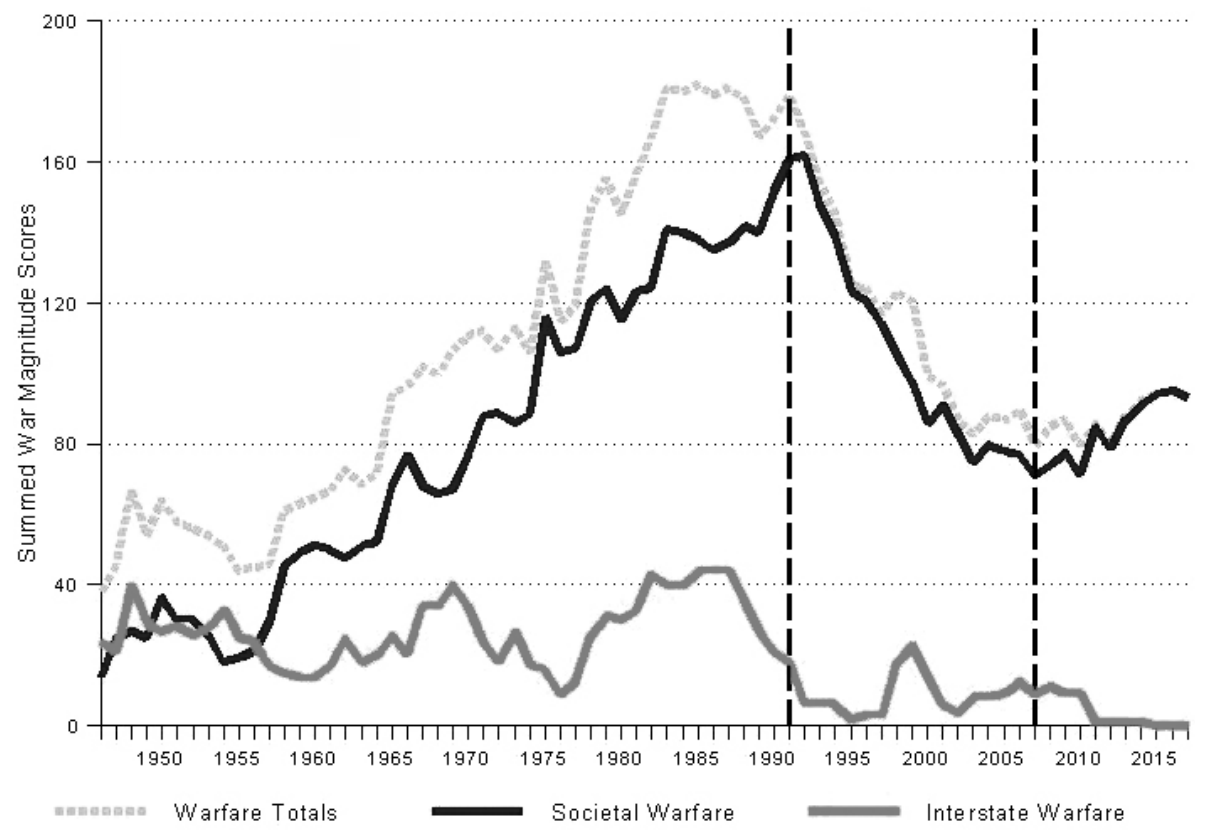

Source: Center for Systemic Peace (2018)

The bipolar nature of the world since the conclusion of the Cold War has come to an end. While the global political stage has seen the number of actors, both state and non-state, grow considerably, assumptions that policymakers can and cannot make have changed. No longer is the capacity to make nuclear weapons limited to the United States and Russia. There are now nine countries possessing these weapons, while fifty-five have nuclear power plants that are used to create nuclear energy. Additionally, North Korea continues to test nuclear weapons and has claimed it is prepared to use its nuclear weapons if attacked. Globalization is becoming less attractive and not even politically viable as an approach for leaders to adopt. Elected populist leaders like Donald Trump, Nigel Farage, and Victor Orban all represent a move towards isolationism. Trump called for a wall between the United States and Mexico, less involvement in the Syrian War, and fewer American dollars spent sustaining the North Atlantic Treaty Organization (NATO). Nigel Farage was one of the key players in the Leave campaign which led to "Brexit" when the United Kingdom voted to leave the European Union. Victor Orban, Prime Minister of Hungary, has refused to cooperate with European policies, such as sanctions against Russia and acceptance of refugees. Sanctions against countries that break international norms are neither enforced nor followed. This may lead to growth of a nuclear black market that relies on a nation's need for so-called "security." Furthermore, 
any progress towards the resolution of violence in conflict zones has stagnated in places like Syria and Venezuela, causing mass displacement of people and straining the welfare systems of countries now inundated with refugees.

According to the Centre for Systemic Peace, armed conflict has been on the rise since 2011. The one saving grace is that interstate warfare is at an all-time low. However, with the rise of non-state actors such as the Islamic State, which obtain their funding from underground support, it is a very real possibility that a terrorist group may obtain nuclear weapons. Is it really a surprise that nations see the existing security framework as unsustainable?

\section{The ElBaradei Proposal}

Dr. Mohamed ElBaradei served as the Director General for the IAEA until 2009. The IAEA released the "ElBaradei Report" in 2005. In this proposal, experts outline different ideas of what an intergovernmental nuclear fuel bank might look like. The approaches incorporate a variety of different options, including the possibility that a fuel bank would not subscribe to direct IAEA ownership, international consortiums of governments, and other additional arrangements that focus on fuel sharing. Namely, the report hastens to note that any and all construction would not disrupt the existing market for nuclear fuel. In all cases, an intergovernmental bank would reinforce free market mechanisms. In some cases, this would place the IAEA in an administrative position over such a bank. The report further suggests joint ownership of any and all banks through the concept of interdependence to protect against regional conflicts. Both governmental and economic interdependence would be at play in the construction of fuel banks. Although the concept of these fuel banks uses the same thread of positive reinforcement of the NPT, it differs in a key way: it impacts everyone rather than just the non-nuclear states.

In fact, the IAEA suggests that the organization need not even be directly involved in particular cases of multilateralism. In one proposal, countries could set up an "international consortium of governments... where governments would ensure the availability of material" (IAEA 2005, 47). Because the report is intentionally vague on the precise applications and procedures of these agreements, it can be difficult to articulate exactly what the ElBaradei report meant in certain instances. However, it can be assumed that multilateral agreements serve a greater purpose in this report, i.e. in order to promote more than just physical fuel sharing. They also support a higher degree of cooperation between countries surrounding nuclear energy. In an ideal world, supranational organizations become redundant due to overwhelming collaborative steps taken consciously by states; however, that is not the world of today. Measures taken to further multilateralism must address potential future pitfalls. 
The report suggests as another option that some "member states would probably be unwilling to allow [the IAEA] to 'receive' spent fuel" (ibid., 104). Although the IAEA is the main actor enforcing the NPT and is primarily responsible for maintaining an orderly system for fuel repositories, its role in specific interstate agreements is limited. As such, direct IAEA involvement is dependent on the role that countries believe to be most beneficial to themselves. Ultimately, enforcement is a matter of accepting such norms. It is up to states to accept and to use multilateral organizations to their best capacity.

In a third option, the IAEA would perhaps play a stronger role. This particular kind of bank would involve nuclear fuel suppliers holding spent fuel reserves indefinitely while the IAEA acted as a guarantor of supplies. In this case, it is useful to have a well-known organization with a record of success as the administrator. However, this also opens up a large amount of risk for the IAEA. Not only would using the IAEA as an administrator be precarious at best, it would also involve a huge amount of additional bureaucracy. In order to make any changes to plants, the IAEA would require approval from the Board of Governors (a total of thirty-five states). Furthermore, the added advantage of having IAEA approval, other than its compliance with international law, is questionable. In the additional arrangements section, there are a variety of suggestions outlined. However, the report notes that due to the IAEA's broad membership, viability of such multilateral banks and the possibility for further cooperation could not be assured (ibid., 70-73).

One further recommendation is an "International Nuclear Fuel Bank." Instead of simply holding spent fuel, this bank would hold a stockpile of lowenriched uranium (LEU). In exchange for maintaining a non-proliferation status, countries would be able to access this fuel for their own peaceful uses of nuclear energy. While this is the fuel bank idea that would best support peaceful sharing of nuclear energy, it remains the most challenging to implement. Not only do the non-proliferation concerns of those countries that would provide the material need to be addressed, the internal political situations of each individual country (regardless of whether they were acting as supplier or consumer states) would also need to be taken into account. Due to the political nature of these concerns, the working group that was in charge of this research determined that it lay outside the scope of the report and it was not pursued any further (ibid., 160161).

\section{The Challenge of Industry}

The concept of an intergovernmental fuel bank continues to face the question of competing interests. Organizations like French EURODIF (European Gaseous Diffusion Uranium Enrichment Consortium), The Urenco Group, and Russian 
Rosatom all compete internationally in this field and represent a serious challenge to the idea of a multilateral bank that can bypass them. As such, they would want to take part in any sort of construction of a multilateral bank. In a way, this benefits the IAEA because when industry takes an interest, it may have the unintended effect of investing so much time and energy that cooperation becomes financially more attractive. What incentives does an intergovernmental fuel bank offer to these industry giants? Access to a large international database of knowledge about nuclear research might be helpful in this case. How will a bank place these industries on equal footing? Resolving this question of balancing power within a fuel bank is not an easy one. It will require a mediator, which may be where the IAEA could come into play. Here a fuel bank would be attractive to North Korea and other nuclear states such as India and Pakistan where the NPT was not. Because of its pariah status on the world stage, North Korea does not have access to the industry standard that such collaboration could provide. India and Pakistan, while both holding significant nuclear arsenals of their own, could benefit from nuclear research conducted in other countries. Would this have made an impact if such a proposal was taken up before any of these countries began to development nuclear weapons? Perhaps not. It is a reality of the world stage that while nuclear energy is a huge benefit to any country, the benefits of nuclear weapons are security-related.

\section{Low-Enriched Uranium Bank in Practice}

Ironically, the LEU Bank is the main proposal that has been taken to a practical working stage and continues to be adapted in multilateral propositions. Although it can be used for peacefully sharing nuclear fuel, the LEU Bank's primary purpose, according the IAEA, is a "mechanism of last resort for Member States in case the supply of LEU to a nuclear power plant is disrupted due to exceptional circumstances." In theory, these banks would reserve up to 90 metric tons of LEU. As of now, there exists a physical reserve of LEU at the International Uranium Enrichment Centre in Angarsk, Russia; a supply guarantee center in the United Kingdom; and an internal LEU reserve in the United States. The IAEA has additionally signed agreements to build an IAEA LEU Bank at the Ulba Metallurgical Plant in Oskemen, Kazakhstan (IAEA 2016).

The nuclear fuel bank opened its doors on August 29, 2017. Because the bank is fully funded on a voluntary basis, the budget of the IAEA will not be affected. One large aspect of the bank that is addressed both in the ElBaradei report and in practical implementation of the LEU Bank is the assurance that construction will not impact the open market. Therefore, it is intrinsically relevant that Kazakhstan produces around 15 percent of the world's uranium reserves, as this means that they are also greatly impacted by this construction. It says a lot about the trust 
for the IAEA that a country so involved in uranium production is willing to host a LEU reserve bank (Xinhua 2017). Concerning the security of the bank, both Russia and China have signed separate transit agreements with Kazakhstan in order to secure transportation for the nuclear fuel. In addition, mechanisms have been set up for the criteria of those applying for LEU: "supply of LEU to a nuclear power plant is disrupted; the Member State is unable to secure LEU from the commercial market, State-to-State arrangements, or by any other means; and the Membership has in place a comprehensive safeguards agreement with the IAEA and is in compliance with this agreement" (IAEA 2007).

During talks, IAEA Director General Amano also stated that "climate change considerations are also important for many countries...the use of nuclear power has undoubtedly led to a substantial reduction in the amount of greenhouse gases that would otherwise have been emitted." Although not immediately relevant to the physical construction of the bank, these remarks made by the IAEA illustrate the intrinsic connection between peaceful uses of nuclear energy and supporting safeguards against proliferation. Despite the fact that this bank is primarily for last resort measures, it plays a role in the non-proliferation regime (IAEA 2015).

As the host of the bank, Kazakhstan has a history of safely using nuclear fuel in a modern capacity. In the 1990s, Kazakhstan was one of the Soviet satellite nations that gave up its nuclear capacity. Nuclear reactors that were built in order to support weapons development instead contributed to causing cancer in many of its citizens. Now Kazakhstan is a non-permanent member of the United Nations Security Council, and with its role on the world stage expanding, it is fitting that Kazakhstan takes on more responsibility in the field of multilateral negotiations regarding nuclear policy (Wood 2017).

\section{Incentivizing or Why It Is Hard to Show Benefits}

Exciting as the development stages of growth are for the LEU Bank, the question reverts back to: why would countries choose to be involved in this initiative? Why would other countries choose to go to this bank and use it when they could simply develop their own programs in secret? One overarching reason is reputation. Most countries are invested in maintaining a positive image on the international stage and do not want to be banished. A key example of this is Iran. Despite the regional power struggle continuing to rage throughout the Middle East between Sunni and Shia, Iran has been left out of global policymaking. This was due to the country progressing with its nuclear program. Due to these nuclear development programs, most of the world engaged in sanctions which left Iran with a weakened economy. Similarly, North Korea was denied access to the world stage. On the other hand, India and Pakistan do not face these same problems. Reputation plays a role in foreign investment, however, and all of these 
countries would hugely benefit from more foreign capital in their respective economies.

Other than reputation, reasons a country might seek nuclear weapons include deterrence, increased international status, domestic political struggles, economic concerns, strategic autonomy, and a tool guaranteeing their independence on the world stage. Keeping these in mind, a country that seeks out nuclear weapons for any of these reasons generally has their continued existence as a country as one of their primary needs. First and foremost, states will always aim to ensure their own livelihood. In order to convince these states of the importance of multilateral cooperation, different tactics must be adopted (Office of Technology Assessment, Congress of the United States 1977, 94-99).

What do all of the above reasons for seeking nuclear weapons have in common? They all are generally incentivized by negative consequences. If states do not follow through on gaining nuclear capacity, then something negative will occur. In turn, this encourages states to engage in an activity which is aimed at preventing negative consequences. In the past, non-proliferation strategies also worked with this set of assumptions in mind. Policies of punishment for countries seeking nuclear weapons or engaging in black market trade focus on encouraging states to NOT act in certain ways.

\section{Positive Incentives with Business and Civil Society}

Instead of using negative incentives, it would better serve the world to focus on positive financial incentives that target both civil society and business. For example, a business that has a financial stake in nuclear fuel sharing may correspondingly lobby a government. This lifts the burden of enforcement so that it does not solely rely on an unreliable supranational structure. Even now, the enforcement of international treaties is dependent on whether or not a country accepts international law applying to their citizens. This is what makes the inclusion of industry so important. In the past, incentivizing countries to engage in the non-proliferation regime has almost always been about governments. The NPT itself is the outcome of compromises between nuclear weapon states and non-nuclear weapon states that guarantees the latter technical and financial assistance for the peaceful uses of nuclear energy.

Economic interdependence can play just as, if not more, important a role in incentivizing a country to act in a way that benefits the global markets in most cases. In particular, financial tools can promote more foreign investment within a government. As such, these governments are less likely to engage in trade wars or conventional tactics of violence to achieve their goals, making it easier for them to engage in diplomacy. Why? Maintaining better relations with countries means more goodwill, better deals, and a more peaceful world without the costs of war. 
Another argument for using business and civil society to seek positive incentives is that reliance on government leaders can backfire. A brief look at the world today shows how unstable governments are proving to be. The elections of populist leaders, continuing conflict, and worsening refugee displacement all suggest that responsibility may fall to citizens to promote peace. This is not to make grandiose claims against governments as strong actors. In some cases, states make the right choices against war. However, due to the inherently chaotic nature of democratic governments, that is not predictable. In other instances, the actions of autocratic governments are easier to forecast. Yet even now, actions of normally easy-to-foresee governments such as Saudi Arabia are not logical. As such, civil society must step forward and take up the burden that states have been irresponsible enough to abandon. In dictatorships such as North Korea, this might be far-fetched. However, other countries, such as India, Israel, and Pakistan, have some degree of reliance on their citizenry.

This is where intergovernmental fuel banks come into play. The main multilateral agreements surrounding the initial steps are created and monitored by states. However, their implementation is accomplished by industry companies, nuclear technology created by research organizations, and negotiation documentation written by legal firms. By combining the two, intergovernmental fuel banks have an opportunity to make an impact that previous strategies have not. Not only will countries be inextricably linked together through international legal agreements, but also by infrastructure and collaborative measures taken by a civil society that has financially invested in the creation of these banks. Furthermore, because of these close ties, countries will also have the opportunity for more dialogue. With more dialogue, the opportunity for more transparency and understanding another culture without preexisting biases arises.

\section{Dual Use}

While optimism has its time and place, the main problem when it comes to nuclear weapons is the concept of dual use. The Nuclear Threat Initiative (NTI 2007) describes it best: "The same technologies that make fuel for nuclear reactors can also produce explosive material for nuclear bombs. Two pathways are available to either make fuel or bomb-material. These are uranium and plutonium pathways."

In short, the issue that faces the non-proliferation regime is that uranium can be enriched into LEU or high-enrichment capacity (HEU). Uranium is enriched by increasing the concentration of uranium-235 (U-235), a fissile isotope. If there is more than 90 percent U-235, then uranium is considered weapon-grade. If there is more than 20 percent $\mathrm{U}-235$, than the uranium is considered HEU. With a higher amount of HEU, it becomes easier to create a nuclear bomb. What makes 
it difficult for non-proliferation investigators to determine whether countries are producing uranium for peaceful or for security-based reasons is that both use the same enrichment technology. One single enrichment plant can utilize connected centrifuges, known as cascades, to create either LEU or HEU (ibid.).

This lack of distinction makes it difficult for countries to determine whether non-nuclear states are aiming to simply produce nuclear energy peacefully or engaging in building weapons. However, this is one of the key benefits of using an LEU Bank. Instead of having to inadvisably trust nations not to engage in creating HEU or weapon-grade uranium, a group of countries could rely upon a bank to always provide them with the necessary fuel. In addition, the nonproliferation regime could be more secure by removing spent fuel, and, in doing so, reduce the risk of either countries or non-state actors using the spent fuel to extract plutonium. Not only is it a more secure system that reduces risk for the nuclear-state countries, it is also more economically viable. Not every country should invest millions in maintaining power reactors and fuel. In fact, it is most often the case that countries ought to be spending money on infrastructure and social programs rather than on security.

\section{Hacking}

Consolidating nuclear energy and fuel increases the possibility of errors and mistakes. Given that the world we live in is of unprecedented technological connectivity, hacking becomes a real concern. In elections from the United States to Western Europe, technology is already being used in ways to disrupt stability. Just one successful hacker could dismantle and bring about massive environmental damage to any country supporting a LEU Bank. When deciding whether or not to implement a bank, this must be taken into consideration. Again, this is where industry could be most influential. Inventing new ways of protecting nuclear fuel is a task best given to civil society because markets promote innovation. By investing in progress within companies and subsequently connecting them to nuclear energy, intergovernmental fuel banks further combine industry and government. The proliferation of nuclear material would go against both entities' interests, and such deals would theoretically incentivize collaboration and the sharing of technology within the nuclear market.

\section{Conclusion}

In short, intergovernmental fuel banks are but one option that countries should take in innovating the current non-proliferation security regime. Promoting the collaboration of civil society and government is the true goal on which to 
be focused. The ElBaradei report offers many options that countries can take in addressing multilateralism in nuclear energy production. However, the report was written and published in 2005 . Would countries that have already gone nuclear (such as India, Pakistan, and North Korea) have taken advantage of an international nuclear fuel bank, instead of the nuclear path? North Korea might not have been swayed by the promise of cooperation and power because its power lies in keeping its citizenry isolated from the rest of the world and cooperation would stymie this goal. As for countries like India and Pakistan, fuel banks might have meant that proliferators such as AQ Khan might not have had as large of a market due to the inherent transparency that these banks support.

Over ten years later, one thing is evident: the situation as it stands cannot continue. Further innovations in nuclear weapons in North Korea along with the growing possibility of acquisition of a nuclear weapon by a terrorist group show the failures of the non-proliferation regime. Innovations need to take center stage. The way that countries think ought to change by focusing on positive reinforcement, rather than on negative consequences. Intergovernmental fuel banks represent an opportunity to take both into account. Hopefully the first IAEA instance of that in Kazakhstan will illustrate to other countries the viability of such a proposal.

\section{References}

Center for Systemic Peace. 2018. “Assessing the Qualities of Systemic Peace." http://www. systemicpeace.org/conflicttrends.html (accessed August 21, 2018).

Office of Technology Assessment, Congress of the United States. 1977. "Nuclear Proliferation and Safeguards." https://www.princeton.edu/ ota/disk3/1977/7705/ 7705.PDF (accessed October 25, 2018).

Goenka, Himanshu. 2016. "Russia Suspends US Plutonium Disposal Agreement." International Business Times, October 3. https://www.ibtimes.com/russia-suspendsus-plutonium-disposal-agreement-2425250 (accessed July 7, 2017).

IAEA (International Atomic Energy Agency). 2005. "Multilateral Approaches to the Nuclear Fuel Cycle Expert Group Report to the Director General of the International Atomic Energy Agency." https://www.iaea.org/publications/documents/infcircs/ multilateral-approaches-nuclear-fuel-cycle-expert-group-report-submitted-directorgeneral-international-atomic-energy-agency (accessed August 21, 2018).

IAEA (International Atomic Energy Agency). 2007. "IAEA Factsheet: Nuclear Energy: The IAEA LEU Bank." https://www.iaea.org/sites/default/files/the-iaea-leu-bank.pdf (accessed July 7, 2017).

IAEA (International Atomic Energy Agency). 2015. "IAEA and Russia Sign Transit Agreement for IAEA Fuel Bank.” June 18. https://www.iaea.org/newscenter/news/ iaea-and-russia-sign-transit-agreement-for-iaea-fuel-bank (accessed July 7, 2017).

IAEA (International Atomic Energy Agency). 2016. "IAEA Low Enriched Uranium Bank." April 13. https://www.iaea.org/topics/iaea-low-enriched-uranium-bank (accessed July 
7, 2017).

John F. Kennedy Presidential Library and Museum. 2017. "Commencement Address at American University, June 10, 1963." https://www.jfklibrary.org/asset-viewer/archives/ TNC/TNC-319-EX/TNC-319-EX (accessed July 7, 2017).

Landay, Jonathan, and David Rohde. 2017. "Exclusive: In Call with Putin, Trump Denounced Obama-era Nuclear Arms Treaty - Sources." Thomson Reuters, February 9. http://www.reuters.com/article/us-usa- trump-putin- idUSKBN15O2A5 (accessed July 7, 2017).

NTI (Nuclear Threat Initiative). 2007. "Proliferation Risks of Nuclear Power Programs." December 1. http://www.nti.org/analysis/articles/risks-nuclear-power-programs/ (accessed July 7, 2017).

Wood, L. Todd. 2017. "Kazakhstan, an Unlikely Purveyor of Peace." Washington Times, May 25. http://www.washingtontimes.com/news/2017/may/25/kazakhstan-anunlikely-purveyor-of-peace (accessed July 7, 2017).

Xinhua. 2017. "IAEA Nuclear Fuel Bank to Open in Kazakhstan in Mid-August. IAEA Nuclear Fuel Bank to Open in Kazakhstan in Mid-August." May 5. http://news. xinhuanet.com/english/2017-05/15/c_136285745.htm (accessed July 7, 2017).

Gabriella Gricius currently works at the Hague Center for Strategic Studies and is an MA Candidate at the University of Groningen. She was awarded her Bachelor's Degree in International Relations and German from Boston University. She is the author of "Analyzing Poland's National Security Strategy," published in 2015 for Boston University’s International Relations Review. Email: gabriella.gricius@ gmail.com 
